\title{
Öğretmen Adaylarının Aile Katılımının Etkililiği ve Aile Katılımına Yönelik Engelleri ile Öğretmenliğe İlişkin Tutum ve Mesleki Öz Yeterliklerinin İlişkisi
}

\author{
DOI: 10.26466/opus.657336
}

\author{
Songül Tümkaya* - Metin Altunkaynak $^{* *}$ \\ * Prof. Dr., Çukurova Üniversitesi, Eğitim Fakültesi, Adana/Türkiye \\ E-Posta: stumkaya@cu.edu.tr ORCID: 0000-0003-0140-4640 \\ ** Doktora Öğrencisi, Çukurova Üniversitesi, Eğitim Fakültesi, Adana/Türkiye \\ E-Posta: metinaltunkaynak01@gmail.com ORCID: 0000-0001-6947-7526
}

$\ddot{O} z$

$\mathrm{Bu}$ araştırmanın amacı, öğretmen adaylarının aile katılımı çalışmalarım ve aile katılımı engellerini yordayan faktörlerin incelenmesidir. Araştırmada ilişkisel tarama modeli kullanılmıştır. Araştırmaya 116 kadın, 51 erkek olmak üzere 167 adet üçüncü ve dördüncü sınıf öğrencileri katılmıştır. Araştırmada veriler "Demografik bilgi formu”, "Aile Katılımı Engelleri Ölçeği Formu”, "Aile Katılımı Etkililik Ölçeğinin Değerlendirilmesi Formu", "Öğretmenliğe İlişkin Tutum Ölçeği" ve "Öğretmen Öz yeterlik Ölçeği" ile toplanmıştır. Araştırmada bağımsız değiş̧kenlerin bağımlı değişkenleri yordayıp yordamadığını belirlemek için çoklu regresyon analizi yapılmıştır. Araştırmada tanımlanan aracı değişkenin etkisi ise üç aşamal çoklu regresyon analiziyle belirlenmiştir. Son olarak Sobel testi kullanılarak, yordayıcı değişkenin Beta değerlerindeki anlamlı farkın ve aracı değişken ile yordayıcı ve yordanan değişkenler arasındaki ilişkinin anlamlılı̆̆ incelenmiştir. Araştırma sonuçlarına göre öğretmenliğe ilişkin tutum ve ögretmenlik öz yeterlilik puanlarının aile katılımının etkililiği puanını anlamlı olarak yordadı̆̆ öğretmenliğe ilişkin tutum ve öğretmenlik öz yeterlilik puanlarının aile katılımının engelleri puanın anlamlı olarak yordadığg, öğretmenliğe ilişkin tutumun aile katılımının etkililiğini ve engellerini yordama derecesi öğretmenlik öz yeterliğinin aile katılımının etkililiğini ve engellerini benzer şekilde istatistiksel olarak anlamlı bir sonuca ulaşılmıştır. Araştırma son bölümünde çeşitli önerilerde bulunulmuştur

Anahtar Kelimeler: Aile katılımının etkililiği, aile katılımı engelleri, öğretmenliğe ilişkin tutum, mesleki öz yeterlik, öğretmen adayları 


\title{
The Effectiveness of Pre-service Teachers' Family Participation and Their Barriers to Family Participation and the Relationship Between Attitude and Professional Self-Efficacy
}

\begin{abstract}
The aim of this study is to investigate the factors that predict the prospective teachers' family participation studies and family participation barriers. In the research, relational screening model was used.. 167 third and fourth grade students, 116 women and 51 men, participated in the study. The data were collected with "Demographic Information Form", "Family Participation Barriers Scale Form", "Family Participation Effectiveness Scale Evaluation Form", Tut Attitude Scale towards Teaching "and" Teacher Self-Efficacy Scale ". Multiple regression analysis was used to determine whether independent variables predicted dependent variables. The effect of the mediator variable defined in the study was determined by three-stage multiple regression analysis. Finally, by using Sobel test, the significant difference in the Beta values of the predictor variable and the relationship between the mediator variable and the predictor and predicted variables were examined. According to the results of the study, it was found that attitude and teaching self-efficacy scores significantly predicted the effectiveness of family participation, teacher attitude and teacher self-efficacy scores significantly predicted the barriers of family participation, and the effectiveness of family participation and obstacles to predicting family participation Similarly, a statistically significant result was reached. In the last part of the research, various suggestions were made.
\end{abstract}

Keywords: Effectiveness of family participation, barriers to family participation, attitudes towards teaching, professional self-efficacy, teacher candidates 


\section{Giriş}

Temel eğitimin ilk basamağını oluşturan ilkokul, bireysel ve toplumsal açdan büyük önem taşır. İlkokul çocuk için yeni bir sosyal ortamdır. Okulda öğrencilerin uyması gereken yeni kurallar, sınıf ve okuldaki diğer öğrenciler ve öğretmenlerle tanışması, öğrenmesi gereken ders ve konular ile kazanacağı değerler okul çevresine uyum sağlamada sorunlarla karşılaşmasına neden olmaktadır. Öğrencilerin olumlu tutum, beceri ve davranışlardan olabildiğince faydalanması ilkokulun işlevsel olmasına bağlıdır (Özbaş, 2013). İlkokulun işlevleri arasında, öğrencilerin sosyalleşerek çevreye ve sınıfa uyum göstermeleri, öğrencilere gerekli temel değerler kazandırma ve öğrencilerin akademik başarılarını artırma şeklinde sıralanabilir (Temel Eğitim Genel Müdürlüğü (TEGM), 2018).

İlkokulların bu işlevleri istenilen düzeyde gerçekleşmesi için öğrencilerin aileleriyle etkili işbirliği yapılması gerekir. Okula başlayan çocuk, sıcak aile ortamından birlikte yaşama kurallarının geçerli olduğu ilk toplumsallaşma kurumu olan okula adım atmış olur. Çocuğun potansiyelini hayata yansıtabilmesi onu destekleyen, onaylayan ve çeşitli görevlerle hayata hazırlayan bir aile ortamında gelişmesiyle mümkündür (TEGM, 2018). Diğer öğrenim kademelerinde olduğu gibi ilkokul açısından da değerlendirildiğinde okul-aile işbirliği ve aile katılımı hayati öneme sahiptir.

Okul-aile işbirliği ve aile katılımı temel eğitimde önemli bir konudur. Aile hayatının katkıları ve okuldaki uzmanlık, okul-aile işbirliğiyle birleştirilebilir. Aileler, çocuklarının ilk eğitimcileridir. Bu nedenle çocuklarının yaşamında en etkili role sahiptirler (Alaçam, 2015). Ailelerden sonra, çocuklarla aile d1şında etkileşime giren ve çocukların öğrenme ve gelişimini etkileyen öğretmenler gelir (Steven, 2003). Bu nedenle öğretmenler aileleri çocuklarının bakımında uzman olarak görmeli ve çocuklarının eğitiminde onlarla işbirliği yapmalıdır (Alaçam, 2015). Bu açıdan bakıldığında, aileleri eğitime ve okulla ilgili faaliyetlere ve ilkokul yıllarından başlayarak konulara dâhil etmek önemlidir. Diğer taraftan öğretmenler, çocuklarının güçlü yönleri ve zorlukları hakkında bilgiye sahip olduklarından, ailelerden bilgi alabildiklerinde, sınıftaki öğrencilerin ihtiyaçlarını daha iyi karşılayabilirler. Çocukları ve ailelerini daha iyi tanıyan öğretmenler çocukların ihtiyaçlarına göre ideal bir program hazırlayabilir. 
Alan yazında göreve başlamadan önce öğretmen adaylarının okul-aile işbirliği konusundaki düşünceleri ve aile katılımı için gerekli bilgileri edinmeleri aile katılımı etkinlikleriyle ilgili duygularını ve uygulamalarını etkileyeceği ortaya konulmuştur (Morris ve Taylor, 1998; Katz ve Bauch, 1999; Zygmunt ve Fillwalk, 2006; Ahioğlu-Lindberg, 2014; Alaçam, 2015). Aile katılımı hakkında bir eğitim almanın öğretmen adaylarının aile katılımı programlarının planlanması ve uygulanmasında bir fark yarattığını düşünülmektedir. Bununla birlikte, bu deneyimin öğretmenlerin uygulaması üzerinde olumlu bir etkiye sahip olmasına rağmen, öğretmenlerin aile katılımı uygulamaları okullarda düşük düzeyde kalmaya devam etmektedir (Morris ve Taylor, 1998).

Öğretmenler her ne kadar aile katılımının önemini kabul etseler de, genellikle aile katılım projelerini uygulamazlar (Alaçam, 2015). Ailelerin katılımının önündeki engeller olarak kavramsallaştırılan bu tür uygulamaları engelleyen etkenler vardır. Alaçam (2015) bu engellerden bazılarını; aile katılımı konusunda yeterli öğretmen eğitimi almamak, öğretmenlerin müfredatı yetiştirmede baskı altında olmaları ve ailelerin okul etkinliklerine vakit ayıramamaları şeklinde ifade etmiştir. Ayrıca, öğretmenlerin tutumları, becerileri ve bilgileri aile katılımının önündeki engeller olarak tanımlanmıştır. Bunları göz önüne alarak, Hornby ve Lafaele (2011) aile katılımının önündeki engelleri açıklamak için kapsamlı bir model geliştirmiştir. Bu modelde, aile, çocuk, aile-öğretmen ve toplumla ilgili olarak dört ana faktör tanımlanmıştır. Farklı bir araştırma çalışmasında, aile engelleriyle karşılaştırıldığında, okul düzeyindeki engellerin aile katılımı üzerinde daha yüksek bir etkiye sahip olduğu ve bu engellerin okulun iklimi ve aile-okul iletişimi ile ilgili olduğu açıklanmiştır.

Öğretmene bağlı faktörler okul seviyesindeki engellerde önemli bir rol oynamaktadır. Öğretmenler, ailelerle iyi iletişim kurma becerisine sahip olmayabilir. Ayrıca, öğretmenler okulda ailelerin katılımını desteklemesine rağmen, bu tür uygulamalar müfredat tarafindan hala desteklenmemektedir (Alaçam, 2015). Öğretmenler aile katılımının önündeki engellerin bir parçası olduğu için, bu engellerin aşılmasında da kilit bir rol oynamaktadır (Savacool, 2011).

Ahioğlu-Lindberg (2014), öğretmen adaylarının aile katılımına yönelik yeterince bilgi sahibi olmadıklarından aile katılımı etkinliklerini önemsemedik- 
lerini ifade etmiştir. Keyser (2006), aile katılımına yönelik engellere ilişkin algılarının lisans yıllarından süregeldiğini ve yapılacak çalışmaların aile katılımına yönelik engellerin belirlenmesi, engellerin anlaşılması ve üstesinden gelinmesi gerektiğini söylemiştir. Öğretmenlerin aile katılımına yönelik engellere ilişkin algıları ile ilgili araştırmalar (Ahioğlu-Lindberg 2014; Demircan, 2012; Hornby ve Lafaele, 2011; Morris ve Taylor, 1998) olmasına rağmen, öğretmen adaylarının aile katılımına yönelik engellere ilişkin algılarına ilişkin yeterli çalışma bulunmamaktadır.

Araştırma değişkenlerden diğeri de öğretmen öz yeterliğidir. Bandura'nın (2001) sosyal bilişsel kuramında ortaya koyduğu kavramlardan olan öz yeterlik algısı, kişinin belirli bir başarıyı gösterebilmek amacıyla kendi yeterliklerine yönelik öz değerlendirmesidir. Öz yeterlilik bir işi başarmak veya bir sorunu çözebilmek için bireyin kendi becerilerine duyduğu inançtır (TEGM, 2018).

Öz yeterliğe sahip kişiler karşılaştıkları sorunlarla başa çıkmada ya da başarısızlık durumlarında pes etmez, yeniden sorunu çözmek için yöntemler geliştirirler. Öz yeterlik öğretmenlerin mesleki yaşamlarında karşılaşabileceği sorunlarla başa çımada önemlidir (Kurt, 2016). Öz yeterlik, öğretmenlerde mücadele gücünü artırarak öğrencilerin eğitiminde daha başarılı yöntemler geliştirmelerine olanak sağlar. Öz yeterliğe sahip öğretmenler, eğitim öğretim süreci içerisinde öğrencilerinin daha iyi bir eğitim almasında gerekli ortamları sağlar ve süreci etkin yürütebilmek için dış paydaşları sürece dâhil etmeye çalışırlar (Hoy ve Spero, 2005).

Öğretmen öz yeterliği, bir öğretmenin, öğrencilerini başarıya yönlendirmek için kendi yeteneklerine inanmasıdır. Öğretmen öz yeterliği ile öğrenci başarısı arasındaki bağlantı incelendiğinde öz yeterlik duygusu güçlü olan öğretmenlerin daha iyi planlamacı, başarısızlıkla daha esnek ve öğrencilere daha açı fikirli ve destekleyici olma eğiliminde oldukları sonuçlarına ulaşılmıştır (By The Room 241 Team, 2018).

Öz yeterliği yüksek öğretmenler ailelerle işbirliği yapmaya yatkın ve birlikte öğrencilerine gelişim ve değişim için ilham verebileceklerine inanırlar. Alan yazınında aile katılımı etkinliklerinin uygulanması ile öğretmenlerin öz yeterlik düzeyleri arasındaki ilişki farklı araştırmalarla ortaya koyulmuştur (Hoy ve Spero, 2005, Alaçam, 2015 ). 
Aile katılımı ile ilgili öğretmen adaylarının etkinliği konusunda yapılan çalışmaların eksikliği önemli bir konudur. Üniversitelerin eğitim fakültesi bölümleri, içeriği Yüksek Öğretim Kurulu tarafından belirlenen standart bir müfredata sahiptir. Bu müfredatta aile katılımı ile ilgili sadece bir zorunlu ders vardır. Aile katılımı ile ilgili sorunların varlığını gösteren araştırmalar (İnal, 2006; Erdoğan ve Demirkasımoğlu, 2010; Yolcu, 2011), öğretmenlerin bu alandaki etkinliğini araştırmak ve etkinliğini artırmak için daha fazla araştırmaya ihtiyaç duyulduğunu göstermektedir.

Aile katılımı eğitimi alan öğretmen adayları almayanlara kıyasla aile katılımı faaliyetlerini uygulamak için "çok hazırlıklı" olduklarını belirtmişlerdir (Katz ve Bauch, 1999). Öğretmen eğitimi programları aile katılımı içindeki öğretim ve etkinliklerle bütünleştirildiğinde, öğretmen adayları kendilerini daha iyi hazırlamış ve olumlu görüşler oluşturmuşlardır (Uludağ, 2008). Ahioğlu-Lindberg (2014) zorunlu aile katılımı dersi alan öğretmen adaylarının aile katılımı konusunda olumlu görüşlere sahip olmasına rağmen, öğretmen adaylarının aile katılımının hem öğretmenlerin hem de ailelerin bazı nedenleri için yeterince desteklenmediğini ortaya çıarmışlardır. Bu çalışma, aile katılımına yönelik engelle ilgili algıların gelişim kaynaklarının öğretmenlik öncesi yıllarda ortaya çıktı̆̆ını göstermektedir.

Aile katılımına ilişkin sorunlar; öğretmenlerin velileri okula bağl1 etkinliklere nasıl dahil edeceklerine ilişkin bilgi ve becerilerinin yetersizliği (Gonzalez-Dehass, 2005), öğretmenlerin aile katılımı etkinliklerinin faydalı olmayacağına dair korkuları, öğretmenlerin yoğun çalışma programlarına veya diğer nedenlere bağlı olarak hem öğretmenlerin hem de ailelerin sınırlı etkileşim fırsatlarının bir sonucu olarak iletişim ile ilgili engellerle karşılaştıkları (Demircan, 2012), öğretmen adaylarının aile ilişkilerinin kalitesi, okuldaki çocukların temel ihtiyaçlarını karşılama ve ailelerin hakları konusundaki temel gereksinimlerini karşılama ile ilgili endişeler olarak özellikle engelleri tanımlamıştır (Baum, 2000). Bu engeller iyi tanımlanırsa, onları anlamak ve üstesinden gelmek daha kolay hale gelir (Keyser, 2006).

$\mathrm{Bu}$ araştırmada, öğretmen adaylarının aile katılımına ilişkin tutumlarına aile katılımına yönelik engellere, aile katılımı etkililiği, öğretmenliğe ilişkin tutum ve öğretmen öz-yeterlik inançlarına ilişkin ölçeklerle aile katılımına ilişkin tutumları incelenmiştir. Literatür taramasından da anlaşıldığı gibi, çalışmaların çoğu öğretmenlerle yapılmıştır (İnal, 2006; Erdoğan ve Demirkası- 
moğlu, 2010; Alaçam, 2015). Türkiye'de öğretmen adaylarıyla yapılan aile katılımı konusunda sınırlı sayıda araştırma vardır (Ahioğlu-Lindberg, 2014; Ateş, 2015). Yapılan çalışmalardan yola çıkılarak araştırma için üniversite öğrencilerinin seçilmesinin nedeni, öğretmenlik öncesi dönem, öğretmenlerin veli ile öğretmenler için etkin bir şekilde çalışmak için gerekli olan bilgi, beceri ve güveni edindikleri zamandır (Tichenor, 2010). Öğrencilerin ilkokul döneminde akademik başarılarının artması, kazanması gereken değerleri benimsemesinin yanında hayatta başarılı ve mutlu olabilmeleri için aile eğitimi etkinliklerini önemli bir yere sahiptir (Özbaş, 2013). Sınıf öğretmeni adaylarının öğretmenliğe başladıkları dönemde aile eğitimleri vermeleri, aile katılımı etkinlikleri düzenleyerek ailelerin eğitim süreçlerinde yer almaları ögretmenin yeteneklerine olan inancını ve performansını artırabilir. Öğretmenlik öncesi dönem aile katılımı konusunda çalışmak üzere gerekli bilgi, beceri ve güveni edinme süresidir (Tichenor, 2010). Ayrıca, öğretmenlerin aile katılımı üzerindeki etkilerine ilişkin inançları aile katılımı uygulamalarını teşvik etme çabalarını öngördüğünden (Epstein ve Dauber, 1991), bu inançlar sınıf ortamlarında aile katılımı uygulamaları hakkında bir fikir verebilir. Bu nedenle araştırma, öğretmen adaylarının aile katılımı çalışmalarını ve aile katılımı engellerini yordayan faktörlerin incelenmesi amaccyla gerçekleştirilmiştir. Öğretim etkinliği inançlarının farklı araştırma çalışmalarında aile katılımı uygulamalarıyla ilişkili olduğu görülmesine rağmen (Wu, 1995; Krizman, 2013), genel özyeterlik inançları çalışmalara entegre edilmemiştir. . Bununla birlikte, bireylerin genel yetenek algisı ile ilgili olarak (Judge, Erez ve Bono, 1998), mesleki öz yeterlik inançlarının, çok çeşitli durumlarda öğretmenlerin performansı üzerinde etkisi vardır (Gist ve Mitchell, 1992). Diğer değişken, aile katılımının önündeki algılanan engeller dikkate alındığında, aile katılımı ile ilgili engellerin anlaşılmasına ve aşılmasına katkıda bulunacaktır.

Diğer tanımlayıcı değişken olan öğretmenliğe ilişkin tutum, bireyin öğretim yeterlikleriyle de ilişkili olan kendi mesleki öz yeterlilikleri hakkındaki yargısıyla da ilişkilidir (Tschannen-Moran, Woolfolk Hoy ve Hoy, 1998). Araştırmacılar tarafından aile katılımının öğretmen adaylarının öğretmenliğe ilişkin tutumlarına etkisi araştırılmıştır. McBride (1991) öğretmen adaylarının aile katılımına yönelik tutumlarını incelemiştir. Çalış- 
maya 271 okul öncesi öğretmen adayı katılmış ve veri toplama aracı Epstein (1987) tarafından geliştirilen araçtan uyarlanmıştır. Nicel veri analizi sonuçları öğretmen adaylarının Epstein tarafından tanımlanan beş ana baba katıl1mına karşı olumlu tutumlara sahip olduklarını göstermiştir. Tichenor (2010) tarafından yapılan bir başka çalışmada öğretmen adaylarının ilköğretim okullarında aile katılımına yönelik tutumlarını araştırmış ve öğretmen adaylarının öğretmenliğe ilişkin tutumları arasında fark olup olmadığını araştırmıştır. Ayrıca öğretmen adaylarının aile katılım etkinliklerine hazırlanmalarına ilişkin duyguları ve öğretmen eğitiminde sağlanması gereken deneyimlere ilişkin inançları da bu çalışmada incelenmiştir. 140'ı üçüncü sınıf ve 117'si son sınıf 257 öğretmen adayından veri toplamak için bir anket kullanılmıştır. Araştırma sonuçları, öğretmen adaylarının tümünün aile katılımı konusunda olumlu tutumlara sahip olduğunu, ancak son sinıf öğretmen adaylarının, üçüncü sınıfta okuyan öğretmen adaylarından daha olumlu tutumlara sahip olduğunu ortaya koymuştur. Öğretmenliğe ilişkin tutum, hem beceriler hem de öz-yeterlik inançları gerekli olduğundan (Bandura, 2001), bu değişkenlerin aile katılım stratejileri üzerinde araştırılması öğretmen adaylarının aile katılımı konusunda yeterliliklerine ilişkin önemli sonuçlar doğuracaktır. Ayrıca, bu çalışma aynı zamanda aile katılımı dersi almanın öğretmen adaylarının aile katılımı ile ilgili öz-yeterlik inançlarını değiştirip değiştirmediğini incelemeyi amaçlamıştır. Aile katılımındaki ders deneyiminin, öğretmen adaylarını aile katılımı uygulamalarına hazırlamada önemli bir rol oynadığı bildirilmiştir (Morris ve Taylor, 1998; Katz ve Bauch, 1999; Zygmunt ve Fillwalk, 2006). Bu bağlamda, mevcut çalışmanın sonuçları aile katılımı etkinliği hakkında bilgi sağlayacak ve bu etkinliklerin içeriğini geliştirmek için önerilerde bulunacaktır. Özetlemek gerekirse, bu çalışma özellikle sınıf öğretmen adaylarının aile katılımı öz-yeterlik inançları ile öğretmenliğe ilişkin tutumlarının araştırılmasına ilişkin alan yazındaki, özellikle Türkiye'deki boşluğu doldurmak için yapılmıştır. Bu doğrultuda araştırmada aşağıdaki sorulara yanıt aranmıştır.

1. Öğretmen adaylarının aile katılımının etkililiği, öğretmenliğe ilişkin tutumlarını ve öz yeterliklerini anlamlı derecede yordamakta mıdır?

2. Öğretmen adaylarının aile katılımı engelleri, öğretmenliğe ilişkin tutumlarını ve öz yeterliliklerini yordamakta mıdır? 
3. Öğretmen adaylarının öğretmenliğe ilişkin tutumları ile aile katılımının etkililik düzeyi arasındaki ilişkiye aile katılımı engelleri düzeyinin aracilık etkisi var midır?

4. Öğretmen adaylarının öğretmenlik öz yeterlik düzeyleri ile aile kattlımı etkililik düzeyi arasındaki ilişkiye aile katılımı engelleri düzeyinin aracilık etkisi var mıdır?

\section{Yöntem}

\section{Araştırma Modeli}

Bu çalışma öğretmen adaylarının aile katılımı kapsamında bağımsız, aracı ve bağımlı değişkenlerle ilişkileri açıklamayı amaçlayan ilişkisel tarama modelinde desenlenmiştir. Bu modelde değişkenler arasında ilişki olup olmadığı herhangi bir etkileme ve değiştirme çabasına girmeden değişkenler arası değişimlerin yönü ve derecesi belirlenmeye çalışılır (Büyüköztürk, 2018). Bu kapsamda araştırma verisi, nicel teknikler kullanılarak çözümlenmiştir. Korelasyonel ve karşılaştırmalı sorular nicel araştırmalar için geçerli yöntemlerdir (Horzum vd., 2016). Bireylerin, grupların ya da örgütlerin belirli özelliklerinin odağa alınarak betimlendiği araştırmalar tarama modelindedir (Berends, 2006). Bu araştırma da tarama modelinde desenlenmiştir. Değişkenlerden birinden yola çıkarak diğerinin yordanmaya çalışıldığı araştırmalar yordayıı ilişkisel tarama araştırması olarak anılmaktadır (Büyüköztürk, Çakmak, Akgün, Karadeniz ve Demirel, 2016).

\section{Örneklem}

Çalışma grubunun belirlenmesinde amaçlı örnekleme yöntemi ve buna bağlı olarak ölçüt örnekleme teknikleri kullanılmıştır. Amaçlı örnekleme zengin bilgiye sahip olduğu düşünülen durumların derinlemesine çalışılmasına olanak sağlamaktadır. Ölçüt örnekleme tekniğindeki amaç ise, önceden belirlenmiş bir dizi ölçütü karşılayan bütün durumların çalışılmasını sağlamaktır (Yıldırım ve Şimşek, 2016). Amaçlı örneklemede araştırmacı kimlerin çalışma grubuna seçileceği konusunda kendi yargısını kullanmakta ve araştırmanın amacına en uygun olan çalışma grubunu belirlemektedir (Balcı, 2007). Bu aç1- 
lardan ele alındığında, çalışma grubunu 2018-2019 eğitim öğretim yılında Çukurova Üniversitesi sınıf öğretmenliği bölümü dördüncü sınıf öğrencilerinin tamamı oluşturmaktadır. Örneklem büyüklüğünü genişletmek için üçüncü sınıf öğrencileri de araştırmaya dâhil edilmiştir. Bu öğrencilerin seçilme nedeni aile katılımı ile ilgili etkinliklerin bu sınıf düzeylerindeki derslerde verilmeye başlamasıdır. Veri toplama süreci sonunda üçüncü ve dördüncü sınıftaki öğrencilerin tamamı olan 192 öğrenciden ölçeklerin uygulandığı günlerde derse gelemeyenler veya ölçeği eksik dolduranlar olmuş, geriye 167 adet ölçek veri analizine uygun olarak araştırmada kullanılmıştır. Katılımc1lara ait demografik özellikleri içeren bilgiler Tablo 1'de sunulmuştur.

Tablo 1. Araştırmaya Katılan Öğretmen Adaylarının Demografik Özellikleri

\begin{tabular}{llll}
\hline Demografik özellikler & Seçenekler & $\mathbf{N}$ & $\mathbf{\%}$ \\
\hline \multirow{2}{*}{ Cinsiyet } & Kadın & 116 & 70 \\
\cline { 2 - 4 } & Erkek & 51 & 31 \\
\hline \multirow{2}{*}{ Yaş } & $18-20$ & 13 & 7,8 \\
\cline { 2 - 4 } & $21-23$ & 154 & 92,2 \\
\hline \multirow{3}{*}{ Mezun olunan lise türüü } & Fen lisesi & 13 & 7,8 \\
\cline { 2 - 4 } & Anadolu lisesi & 108 & 64,7 \\
\cline { 2 - 4 } & İmam hatip Lisesi & 3 & 1,8 \\
\cline { 2 - 4 } & Diğer & 43 & 25,7 \\
\hline \multirow{2}{*}{ Sinıf } & 3. sinıf & 94 & 56,3 \\
\hline \multirow{4}{*}{ Genel Not Ortalamasi } & 4. sinıf & 73 & 43,7 \\
\cline { 2 - 4 } & $1.00-1.99$ & 2 & 44,3 \\
\cline { 2 - 4 } & $2.00-2.99$ & 76 & 45,5 \\
\cline { 2 - 4 } & $3.00-3.50$ & 15 & 100 \\
\cline { 2 - 4 } & $3.51-4.00$ & 167 & \\
\hline
\end{tabular}

Tablo 1'de görüldüğü gibi katılımcıların çoğunluğu kadın öğrenciler $(n=116, \% 70)$ olup erkek öğrenciler $(n=51, \% 31)$ şeklindedir. Araştırmaya katılan öğrencilerin 18-20 yaş arası olan öğrenciler $(\% 7,8)$ azınlıkta olup, öğrencilerin çoğunluğu (\%92,2) 21-23 yaş aralığındadır. Mezun olunan lise türüne göre öğrenciler en fazla (\%64,7) Anadolu lisesi mezunu olup, ölçekte diğer seçeneğini işaretleyenlerin oranı \%25,7' dir. Diğer olarak belirtikleri lise türü ise temel lisedir. Örnekleme alınan sınıfların \%56,3’ü üçüncü sınıf öğrencisi olup, dördüncü sinıfta okuyan öğrencilerin oranı $\% 43,7^{\prime}$ dir. Genel not ortalaması ağırlıklı olarak 2.00-2.99 (n=74, \%44,3) ile 3.00-3.50 (n=76, \%45,5) arasındadır. Sadece iki öğrencinin $(\% 1,2)$ not ortalaması 1,00-1,99 arasındadır. 


\section{Veri Toplama Araçları}

Araştırmada öğretmen adaylarının aile katılımına ilişkin verileri; “Demografik bilgi formu", "Aile Katılımı Engelleri Ölçeği Formu”, “Aile Katılımı Etkililik Ölçeğinin Değerlendirilmesi Formu”, "Öğretmenliğe İlişkin Tutum Ölçeği" ve "Öğretmen Öz yeterlik Ölçeği" ile toplanmıştır.

Demografik Bilgi Formu: Öğretmen adayları ile ilgili kişisel bilgileri edinme amacıyla bu konuda yapılan çalışmaların aile katılımı değişkenleri ile ilişkili olduğu ifade edildiği için öğrencilerin cinsiyetleri, yaşları, mezun oldukları lise türü, sınıfları, genel not ortalamaları, aile katılımı dersi alıp almadıkları ve aile katılımı yöntemlerini uygulamaya yönelik becerilerin değerlendirilmesini içeren bilgiler yer almaktadır. Bu formda toplam 8 madde bulunmaktadır. Bu demografik bilgileri ölçeklerden toplanan diğer bilgilerle ilişkilendirmek ve her bir demografik bilginin araştırmanın değişkenleriyle ilişkisini öğrenmek için kullanılmıştır.

Aile Katılımı Engelleri Ölçeği Formu: Epstein ve Salinas (1993) tarafından geliştirilmiş ve Demircan (2012) tarafından Türkçeye uyarlanmıştır. Ölçeğin cronbach Alfa katsayısı ile ölçülen güvenilirlik katsayısı .74 olarak bulunmuştur. Bu ölçek 10 madde ve bir faktörden oluşmasına rağmen, Demircan (2012), madde-toplam korelasyon testine göre madde 9 'uygulanamaz' (.238) olduğu için düzeltilmiş ve bir maddeyi ana çalışmasının dişında tutmuştur. Anket 9 maddeden oluşan 5 puanlık bir likert ölçeğe dayanmaktadır. Ölçek maddeleri (1) "hiç katılmıyorum" ve (5) "kesinlikle katılıyorum”" şeklinde puanlanmıştır. Tek boyutlu olan ölçeğin Cronbach's Alpha seviyesi $\alpha=.76$ olarak bulunmuştur.

Aile Katılımı Etkililik Ölçeğinin Değerlendirilmesi Formu: Stuckey (2010) tarafından öğretmen adaylarının eğitimde aile katılımına yönelik etkinlik düzeylerini belirlemek için geliştirilmiş ve Alaçam (2015) tarafından Türkçeye uyarlanmıştır. Anket 11 maddeden oluşan 6 puanlık likert ölçeğe dayanmaktadır. İki boyutlu olan ölçeğin ilk boyutu bir kişinin bir görevi tamamlamada sahip olabileceği güven duygusu, ikinci boyutu ise bir görevin görevle ilgili davranışlarının sonucunu ele alan beklenti inancıdır. Ölçek maddeleri (1) "kesinlikle katılmıyorum" ve (6) "kesinlikle katıliyorum" şeklinde puanlanmıştır. Araştırmamızda Cronbach's alpha seviyesi $\alpha=.93$ bulunmuştur. 
Öğretmenliğe İlişkin Tutum Ölçeği: Erkuş, Sanlı, Bağlı ve Güven (2000) tarafından öğretmen adaylarının öğretmenlik mesleğine ilişkin tutumlarına yönelik geliştirilmiştir. Deneme formunda 38 madde yer alırken, yapılan ön uygulama ve analizler sonucunda, anket 22 maddeden oluşan 5 puanlık likert ölçeğe dayanmaktadır. Ölçek maddeleri (5) "tamamen uygun" ve (1) "hiç uygun değil" şeklinde puanlanmıştır. Tek boyutlu olan ölçeğin Cronbach Alfa katsayısı .99 olarak bulunmuştur. Araştırmamızda Cronbach's Alpha seviyesi $\alpha=.76$ bulunmuştur.

Öğretmen Öz yeterlik Ölçeği: Tschannen-Moran ve Hoy (2001) tarafından geliştirilmiş ve Çapa, Çakıroğlu ve Sarıkaya (2005) tarafından Türkçeye uyarlanmıştır. Geçerlik çalışmaları kapsamında doğrulayıcı faktör analizi ve Rasch ölçme modeli kullanılmıştır. Anket 24 maddeden oluşan 5 puanlık dokuz eşit aralıktan oluşan bir likert ölçeğine dayanmaktadır. Üç boyutlu olan ölçeğin birinci boyutu öğrenci katılımını sağlama, ikinci boyutu sınıf yönetimi ve üçüncü boyutu öğretim stratejisi ile ilgili maddelerden oluşmaktadır. Cronbach Alfa katsayısı 99 olarak bulunmuştur. Ölçek maddeleri (1) "yetersiz" ve (5) "çok yeterli" şeklinde puanlanmış dokuz eşit aralıktan oluşmaktadır. Araştırmamızda Cronbach's Alpha seviyesi $\alpha=.92$ bulunmuştur.

\section{Verilerin Analizi}

Ölçekler bilgisayar ortamına aktarılarak veri seti oluşturulmuştur. Ardından kayıp veri ile uç değer analizleri yapılmış ve analize uygun hale getirilmiştir. Analiz öncesinde ölçeklerdeki ters maddeler düzeltilmiş ve boyutlar bazında toplam puanlar hesaplanmıştır. Daha sonra veri setinin çok değişkenli analizlere uygunluğu değerlendirilmiştir. Bu kapsamda ilk olarak veri setinin normallik varsayımını karşılayıp karşılamadığını belirlemek üzere basıklık ve çarpıklık katsayı değerlerine bakılmıştır. İstatistik çalışmalarında en yaygın kullanılan dağılım normal dağılımdır.

Normal dağılım simetriktir. Maddelere ilişkin normallik varsayımını kontrol etmek için basıklık ve çarpıklık katsayıları hesaplanmış ve hiçbir maddenin basıklık ve çarpıklık katsayı değerinin $-10<$ basıklık $<10$ ve $-3<$ çarpıklık<3 aralığı dışında olmadığı (Kline, 2005) doğrulanmıştır. Bu kapsamda basıklık ve çarpıklık katsayı değerlerinin Aile Katılımı Engelleri Ölçeği Formu için çarpıklık katsayısı -1,498 ve basıklık katsayısı 5,117'dir. Aile Katılımı Etkililik Ölçeğinin Değerlendirilmesi Formu için çarpıklık katsayısı - 
0,480 ve basıklık katsayısı 0,552'dir. Öğretmenliğe İlişkin Tutum Ölçeği çarpıklık katsayısı 1,494 ve basıklık katsayısı 3,371'dir. Öğretmen Öz yeterlik Ölçeği için çarpıklık katsayısı-0,293 ve basıklık katsayısı -0,401'dir. Bu sonuçlara göre veri setinin normal dağılım gösterdiği sonucuna ulaşılmıştır (Bkz., Kline, 2005). Araştırmada bağımsız değişkenlerin bağımlı değişkenleri yordayıp yordamadığın belirlemek için çoklu regresyon analizi yapılmıştır. Araştırmada tanımlanan aracı değişkenin etkisi ise üç aşamalı çoklu regresyon analiziyle belirlenmiştir (Çokluk vd., 2012). Aracılık ilişkisi, iki değişken arasındaki ilişkinin üçüncü bir değişken tarafından sağlandığı durumdur (Baron ve Kenny, 1986). Aracılık ilişkisinden açılayabilmek amacıyla Baron ve Kenny, (1986) üç aşamalı bir regresyon analizini önermektedir. Buna göre ilk aşamada aracı değişken üzerindeki bağımsız değişken etkisine, ikinci aşamada bağımlı değişken üzerindeki bağımlı değişken etkisine ve son olarak bağımlı değişken üzerinde hem bağımsız hem de aracı değişkenin etkisine bakılmaktadır. Bu analiz sonucunda; ilk olarak, bağımsız ve bağımlı değişken arasında anlamlı ilişki olmalıdır. Daha sonra aracı değişken ile bağımlı değişken arasında anlamlı ilişki olmalı ve son olarak aracı değişken ile bağımlı değişken arasında, hem aracı değişken hem de bağımsız değişken, bağımlı değişkeni birlikte yordadığında da anlamlı bir ilişki olması gerekir. Bununla birlikte aracı değişken ile bağımsız değişken aynı anda regresyon analizine girdiği zaman daha önce bağımsız ve bağımlı değişken arasındaki anlamlı ilişkinin azalması ya da önceki anlamlılık düzeyinin tamamen ortadan kalkması gerekmektedir. En son Sobel testi kullanılarak, yordayıcı değişkenin Beta değerlerindeki anlamlı farkın ve aracı değişken ile yordayıcı ve yordanan değişkenler arasındaki ilişkinin anlamlılığı incelenmektedir (Sobel, 1982' den Akt. Kablan, 2012). Ölçeklerin tamamlanması yaklaşık 20 dakika sürmüştür.

\section{Bulgular}

Tablo 2'de Öğretmen adaylarının öğretmenliğe ilişkin tutumları ve öz yeterlilik düzeylerinin, aile katılımının etkililiğini yordama derecesine yönelik çoklu regresyon analizi sonuçları sunulmuştur.

Tablo 2'deki çoklu regresyon analizi sonuçlarına göre, öğretmenliğe ilişkin tutum ve öğretmenlik öz yeterlilik puanlarının aile katılımının etkililiği puanının anlamlı olarak yordadığı görülmektedir $(\mathrm{F}=37,072 ; \mathrm{p}<, 01)$. 
Öğretmenliğe ilişkin tutum ve öğretmenlik öz yeterlilik puanları, aile katıllmının etkililiği puanının toplam varyansının yaklaşık \%31'ini açıklamaktadir.

Tablo 2. Aile Katılımının Etkililiğinin Yordanmasına İlişkin Çoklu Regresyon Sonuçları

\begin{tabular}{llllll}
\hline & B & Standart Hata B & $\beta$ & t & p \\
\hline Sabit & 2,682 &, 425 & - & 6,317 &, 000 \\
\hline Öğretmenliğe İlişkin Tutum &,- 218 &, 109 &,- 130 & $-1,995$ &, 000 \\
\hline Öğretmen Öz Yeterliği &, 355 &, 043 & -534 & 8,186 &, 002 \\
\hline $\mathrm{R}=0,560 \quad \mathrm{R}^{2}=0,314$ & & & & & \\
\hline $\mathrm{F}=37,072 \quad \mathrm{p}=0,000$ & & & & & \\
\hline
\end{tabular}

Tablo 2'de görülen standardize edilmiş regresyon katsayılarına ( $\beta$ ) göre yordayıc değişkenlerin aile katılımının etkililiği değişkeni üzerindeki önem sırası, öğretmen öz yeterliği $(\beta=, 534)$ ve öğretmenliğe ilişkin tutum düzeyi $(\beta=, 130)$ şeklindedir. Regresyon katsayılarının anlamlılı̆̆ına ilişkin t-testi sonucu incelendiğinde, öğretmenliğe ilişkin tutum $(t=-1,995 ; p<, 01)$ ve öğretmenlik öz yeterliliğii $(t=8,816 ; p<, 01)$ değişkenleri, aile katılımının etkililiğinin anlamlı yordayıcıları olduğu sonucuna ulaşılmıştır.

Tablo 3'te öğretmen adaylarının öğretmenliğe ilişkin tutumları ve öz yeterlilik düzeylerinin, aile katılımı engelleri düzeyini yordama derecesine yönelik çoklu regresyon analizi sonuçları görülmektedir.

Tablo 3. Aile Katılımının Engelleri Düzeyinin Yordanmasına İlişkin Çoklu Regresyon Sonuçlan

\begin{tabular}{llllll}
\hline & B & Standart Hata B & $\beta$ & $\mathbf{t}$ & $\mathbf{p}$ \\
\hline Sabit & 3,890 &, 334 & - & 611,653 &, 000 \\
\hline Öğretmenliğe İlişkin Tutum &,- 213 &, 086 &,- 191 & $-2,472$ &, 002 \\
\hline Öğretmen Öz Yeterliği &, 029 &, 034 &, 065 &, 844 &, 000 \\
\hline $\mathrm{R}=0,206 \quad \mathrm{R}^{2}=0,43$ & & & & & \\
\hline $\mathrm{F}=3,606 \quad \mathrm{p}=0,029$ & & & & \\
\hline
\end{tabular}

Tablo 3'teki çoklu regresyon analizi sonuçlarına göre, öğretmenliğe ilişkin tutum ve öğretmenlik öz yeterlilik puanlarının aile katılımının engelleri puanının anlamlı olarak yordadığı görülmektedir $(F=3,606 ; p<, 01)$. Öğretmenliğe ilişkin tutum ve öğretmenlik öz yeterlilik puanları, aile katılımının engelleri puanının toplam varyansının yaklaşık \%43'ünü açıklamaktadır. Tabloda gö- 
rülen standardize edilmiş regresyon katsayılarına $(\beta)$ göre yordayıcı değişkenlerin aile katılımının engelleri değişkeni üzerindeki önem sırası, öğretmenliğe ilişkin tutum düzeyi $(\beta=, 191)$ ve öğretmen öz yeterliği $(\beta=, 065)$ biçimindedir. Regresyon katsayılarının anlamlılığına ilişkin t-testi sonucu incelendiğinde, öğretmenliğe ilişkin tutum $(t=-2,472 ; p<, 01)$ ve öğretmenlik öz yeterliliği $(t=, 844 ; p<, 01)$ değişkenlerinin, aile katılımının engelleri puanının anlamlı yordayıcıları olduğu sonucuna ulaşılmıştır.

Araştırmada öğretmen adaylarının öğretmenliğe ilişkin tutumları ile aile katılımının etkililik düzeyi arasındaki ilişkide aile katılımı engelleri düzeyinin aracılık etkisini tespit etmeye yönelik aşamalı çoklu regresyon analizi sonuçları Tablo 4'te sunulmuştur.

Tablo 4. Öğretmenliğe İlişkin Tutumlan ile Aile Katılımının Etkililik Düzeyi İlişkisinde Aile Katılımı Engellerinin Aracılık Etkisinin Yordanmasına İlişkin Çoklu Regresyon Analizi Sonuçlan

\begin{tabular}{|c|c|c|c|c|c|}
\hline Birinci Aşama & B & Standart Hata B & $\beta$ & $\mathrm{t}$ & $\mathrm{p}$ \\
\hline Öğretmenlik Tutum & 2,932 & ,214 &,- 151 & $-1,956$ & ,001 \\
\hline \multicolumn{6}{|l|}{$\mathrm{R}=, 151 \mathrm{R}^{2}=0,23 \mathrm{~F}=3,826 \mathrm{p}=0,00$} \\
\hline İkinci Aşama & B & Standart Hata B & $\beta$ & $\mathrm{t}$ & $\mathrm{p}$ \\
\hline Öğretmenlik Tutum &,- 194 & ,068 &,- 219 & $-2,872$ & ,019 \\
\hline \multicolumn{6}{|l|}{$\mathrm{R}=, 219 \mathrm{R}^{2}=0,48 \mathrm{~F}=8,247 \mathrm{p}=0,005$} \\
\hline Üçüncü Aşama & B & Standart Hata B & $\beta$ & $\mathrm{t}$ & $\mathrm{p}$ \\
\hline Öğretmenlik Tutum & 052 & ,052 & ,078 & 1,011 & 743 \\
\hline Aile Katılım Etkililiği &,- 233 & ,087 &,- 207 & $-2,686$ &, 000 \\
\hline $\mathrm{R}=, 232 \mathrm{R}^{2}=0,54 \mathrm{~F}=4,635 \mathrm{p}=0,011$ & & & & & \\
\hline
\end{tabular}

Tablo 4'te yer alan üç aşamalı regresyon analizinin birinci aşamasında, öğretmenliğe ilişkin tutumun aile katılımının etkililiğini yordama derecesine bakılmış ve anlamlı bir sonuç bulunmuştur $(\beta=-, 151, t=1,956 ; p<, 01)$. İkinci aşamada ise öğretmenliğe ilişkin tutumun aile katılımı engellerini yordama derecesine bakılmış ve benzer şekilde istatistiksel olarak anlamlı bir sonuca ulaşılmıştır $(\beta=, 219, t=2,872 ; p<, 01)$. Üçüncü aşamada ise aile katılımı etkililiği değişkenin aracılık etkisini test etmek amacıyla öğretmenlik tutumu ile birlikte aile katılımı engelleri değişkenini yordama derecesi irdelenmiştir. Bu analiz sonuçlarına göre, ikinci aşamadaki iki değişken arasındaki Beta düzeyinin yükselerek -,219'dan 0,78'e çıkmış ve öğretmenlik tutumu ile aile katılımı engelleri arasındaki ilişkinin istatistiksel olarak olmadığı sonucuna ulaşılmıştır ( $\beta=, 078, t=1,011 ; p>, 05)$. Öte yandan Tablo 4'teki birinci analizde öğretmenlik tutum puanın, aile katılımının 
etkililiği puanının toplam varyansının \%23'ünü, ikinci aşamada aile katılımı engelleri puanının \%48'ini açıkladığı gözlemlenmiştir. Üçüncü aşamada ise öğretmenlik tutumu ile birlikte aile katılımının etkililiği puanının yordayıcı etkisi eklendiğinde, aile katılımı engelleri puanının toplam varyansının \%54'ü kadar büyük bir bölümünü açıkladığı sonucuna ulaşılmıştır. Bunlarla birlikte araştırmada öğretmenlik tutum ve aile katılımı engelleri ilişkisi incelendiğinde aile katılımının etkililiği aracı rolünü test etmek için Sobel test istatistiği kullanılarak $z$ değerinin 3,19 $(p<0.01)$ olduğu sonucuna ulaşılmıştır. Bu durumda aile katılımı engelleri değişkeni açısından, aile katılımı etkililiğinin önemli bir aracı değişken olduğu, bu değişkenin sabitlendiği bir durumda öğretmenlik tutumu değişkenin etkisinin istatistiksel olarak anlamlı olmadığı bulgusuna ulaşılmıştır.

Araştırmada öğretmen adaylarının öğretmenlik öz yeterlik düzeyleri ile aile katılımı etkililik düzeyi arasındaki ilişkiye aile katılımı engelleri düzeyinin aracılık etkisini tespit etmeye yönelik aşamalı çoklu regresyon analizi sonuçları ise Tablo 5 'te sunulmuştur.

Tablo 5. Öğretmenlik Öz Yeterlik ile Aile Katılımının Etkililik Düzeyi İlişkisinde Aile Katılımı Engellerinin Aracılık Etkisinin Yordanmasına İlişkin Çoklu Regresyon Analizi Sonuçları

\begin{tabular}{|c|c|c|c|c|c|c|}
\hline Birinci Aşama & & $\mathrm{B}$ & Standart Hata B & $\beta$ & $\mathrm{t}$ & $\mathrm{p}$ \\
\hline $\begin{array}{l}\text { Ö̈gretmenlik } \\
\text { Öz yeterlik }\end{array}$ & Aile Kat. Etk. & 362 & ,044 &, 545 & 8,301 & , 010 \\
\hline $\begin{array}{l}R=, 545 R^{2}=0,297 \\
F=68,903 \quad p=0,00\end{array}$ & & & & & & \\
\hline İkinci Aşama & & $\mathrm{B}$ & Standart Hata B & $\beta$ & $\mathrm{t}$ & $p$ \\
\hline $\begin{array}{l}\text { Öğretmenlik } \\
\text { Öz yeterlik }\end{array}$ & Aile Kat. Eng. & ,036 & ,035 & 081 & 1,033 &, 000 \\
\hline $\begin{array}{l}R=, 081 \quad R^{2}=0,7 \\
F=1,068 \quad p=0,303\end{array}$ & & & & & & \\
\hline Üçüncü Aşama & & B & $\begin{array}{ll}\text { dart } & \beta \\
B & \end{array}$ & $\mathrm{t}$ & $\mathrm{p}$ & \\
\hline $\begin{array}{l}\text { Öğretmenlik } \\
\text { Öz yeterlik } \\
\text { Aile Katılım } \\
\text { Etkililiği }\end{array}$ & Aile Kat. Eng. & $\begin{array}{l}, 091 \\
, 003\end{array}$ & $\begin{array}{l}, 062 \\
, 041\end{array}$ & $\begin{array}{l}137 \\
, 006\end{array}$ & $\begin{array}{l}1,478 \\
, 064\end{array}$ & $\begin{array}{l}, 002 \\
, 000\end{array}$ \\
\hline $\begin{array}{l}\mathrm{R}=, 140 \mathrm{R}^{2}=0,20 \\
\mathrm{~F}=1,630 \quad \mathrm{p}=0,199\end{array}$ & & & & & & \\
\hline
\end{tabular}


Tablo 5'te yer alan üç aşamalı regresyon analizinin birinci aşamasında, öğretmenlik öz yeterliğinin aile katılımının etkililiğini yordama düzeyi araştırılmış ve anlamlı bir sonuca ulaşılmıştır $(\beta=, 545, t=8,301 ; p>, 05)$. İkinci aşamada, öğretmenlik öz yeterliğinin aile katılımı engellerini yordama derecesi araştırılmış ve birinci aşamada olduğu gibi istatistiksel olarak anlamlı bir sonuca ulaşılmıştır ( $\beta=, 081, t=1,033 ; p>05)$. Üçüncü aşama olan son aşamada ise aile katılımı etkililiği değişkeninin aracılık etkisini test etmek amacıyla öğretmenlik öz yeterlik ile beraber aile katılımı engelleri değişkenini yordama derecesi irdelenmiştir. Analiz sonuçlarına göre, iki değişken arasındaki Beta değerinin $0,35^{\prime}$ ten 0,62 'e yükseldiği ve öğretmenlik öz yeterlik ile aile katılımı engelleri arasındaki ilişkinin istatistiksel olarak anlamlılığını koruduğu bulgusuna ulaşılmıştır $(\beta=, 137, \mathrm{t}=1,478$; $\mathrm{p}>$,05). Öte yandan analizin birinci aşamasında öğretmenlik öz yeterlik puanının, aile katılımı etkililiği puanının toplam varyansının \%2'sini, ikinci aşamada ise önceki aşamaya göre artarak aile katılımı engelleri puanının toplam varyansının \%7'sini açıkladığı bulgusuna ulaşılmıştır. Üçüncü aşama olan son aşamada ise öğretmenlik öz yeterliğiyle birlikte aile katılımı etkililiği puanının yordayıcı etkisi eklendiğinde, iki değişkenin aile katılımı engelleri puanının toplam varyansının \%20'lik bölümünü açıkladığı bulgusuna ulaşılmıştır. Bu bulgularla birlikte araştırmada öğretmenlik öz yeterlik ve aile katılımı engelleri ilişkisinde aile katılımı etkililiğinin aracı rolünün anlamlılık derecesini tespit etmek amaciyla Sobel test istatistiği ile hesaplanan z değeri 2,37 (p<0,05) olarak bulunmuştur. Üç aşamalı regresyon analizi ve Sobel testi sonuçlarına göre, aile katılımı etkililiğinin önemli bir aracı değişken olduğu, öte yandan öğretmen öz yeterlik değişkeninin ise aile katılımı etkililiği değişkenini yordadığı sonucuna ulaşılmıştır.

\section{Tartışma ve Sonuç}

Öğretmen adaylarının aile katılımı kapsamında bağımsız, aracı ve bağımlı değişkenlerle ilişkileri açıklamayı amaçlayan araştırmada, öğretmenliğe ilişkin tutum ve öğretmenlik öz yeterlilik puanlarının aile katılımının etkililiği puanını anlamlı olarak yordadığı görülmektedir. Aile katılımının etkililiği değişkeni üzerindeki önem sırası, öğretmen öz yeterliği ve öğretmenliğe iliş- 
kin tutum düzeyi şeklindedir. Bu sonucun, öz yeterliği yüksek ve öğretmenliğe ilişkin tutumları olumlu olan öğretmen adaylarının daha etkin bir öğretim süreci için aile katılımına önem verdiklerini gösterdiği değerlendirilmektedir. Öğretmen adayları kendilerini mesleki açıdan ne kadar yeterli olarak görürse aileler ile çalışmaya da o kadar olumlu yaklaşmaktadır. Kendi becerilerine ve yeteneklerine güvenen öğretmen adayları aile katılımında karşılaşlabilecek engellerin de üstesinden gelebileceğini düşünebilir. Alan yazın incelendiğinde Ajanga (2011) öz yeterliği düşük olan öğretmenlerin öğrencilerin başarılarında olumlu etkileri olmayacağına ve etkili bir aile katılımı kuramayacağını ifade etmiştir. Kaya (2007), araştırmasında öz yeterlilik inancı yüksek olan öğretmen adaylarının ailelere karşı daha olumlu bir yaklaşım benimsedikleri sonucuna ulaşmıştır. Yine öz-yeterliği yüksek öğretmen adaylarının, öğretmenliklerinde aile katılım uygulamalarına daha sık yer verdiklerini (Krizman, 2013) ortaya koyan çalışmalar araştırmamızın sonucuyla paralel sonuçlara ulaşıldığını ortaya koymuştur. Ateş (2015), öğretmen adaylarının öğretmenliğe ilişkin tutumlarının yüksek düzeyde olması için aile katılımı konusunda bilgi ve becerilerinin desteklenmesi gerektiğini ifade etmiştir. Sını öğretmeni adaylarının aile katılımına ilişkin olumlu tutum geliştirmeleri için aile katılım çalışmalarının farklı derslerin içeriğine eklenmesi (Ateş, 2015) yoluyla öğretmenliğe başladıklarında aile katılımı çalışmalarını uygulama eğiliminde olurlar. Bu nedenle öğretmen adaylarının ailelere yönelik gözlem yapma ve aile katılım etkinliklerini kolaylaştırmak (Uludağ, 2008) için onların öğretmenlik öz yeterlikleri artırılarak ve öğretmenliğe ilişkin olumlu tutuma sahip olmaları önemli bulunmuştur.

Öğretmen adaylarının öğretmenliğe ilişkin tutum ve öğretmenlik öz yeterlilik puanlarının aile katılımının engelleri puanını anlamlı olarak yordadığı sonucuna ulaşılmıştır. Aile katılımının engelleri değişkeni üzerindeki önem sırası, öğretmenliğe ilişkin tutum düzeyi ve öğretmen öz yeterliği şeklindedir. Öğrencilerin gelişimi eğitime bağlıdır. Ancak hiçbir eğitim sistemi öğretmeninin kalitesinden daha iyi olamaz ve öğretmen yardımı olmadan beceri geliştirilemez. Üniversitede öğretmen adaylarına 'Öğretmenlik Uygulaması' imkânları sunulmaktadır. Bu uygulama öğretmenlerin davranışı, tutumu ve ilgisi sınıf öğretmenleri öğrencilerinin kişiliğini şekillendirmede yardımcı olur. Tutum, belirli bir zamanda tepki verme eğilimidir. Bu nedenle öğretmen adaylarının öğretmenliğe ilişkin tutumları aile katılımı dâhil birçok açıdan 
hayati öneme sahiptir. Ancak aileyi eğitim sürecine dâhil etme ve böylece çocuğun daha etkili bir eğitim alması gerekirken okul, öğretmen ve ailelerden kaynaklanan engellerden dolayı aile katılımı etkin biçimde uygulanamamaktadır (Abbak, 2008). Ateş (2015), aile katılımını engelleyen nedenleri, ögretmenlerin aile katılım çalışmalarını yeterince bilmeyişleri, çalışmaları nasıl uygulanacağını bilmemeleri, aile katılım çalışmalarının fazla zaman alacağını düşünmeleri olarak sıralanmaktadır. Araştırmamıza katılan öğretmen adaylarının da aile katılımı konusunda öğretmenliğe ilişkin tutumlarının önündeki engelleri aşmaları için üniversitede aile katılımı derslerinin programa eklenmesi, öğretmenlik uygulaması esnasında aile katılımı etkinliklerini gözlemlemeleri ve dersine girdiği sınıftaki öğrencilerin aileleriyle aile katılımı yapmalarına imkân verilmelidir. Aile katılım etkinliklerine ayrılan zamanın ileriye yönelik birçok sorunun aşımasına katkı sunulacağının öğretilmesi beklenir.

Öğretmen adaylarının öğretmenliğe ilişkin tutumun aile katılımının etkililiğini ve engellerini yordama derecesi benzer şekilde istatistiksel olarak anlamlı bir sonuca ulaşılmıştır. Öğretmenlik tutum puanın, aile katılımının etkililiğini düşük, aile katılımı engellerini ise daha fazla açıkladığı sonucuna ulaşılmıştır. Öğretmenlik tutumu ile birlikte aile katılımının etkililiği puanının yordayıcı etkisi eklendiğinde, aile katılımı engelleri puanının toplam varyansının büyük bir kısmını açıkladığı sonucuna ulaşılmıştır. Bunlarla birlikte araştırma bulgularına göre öğretmenliğe ilişkin tutum ile aile katılımı engelleri ilişkisinde aile katılımının etkililiği aracı rolü incelendiğinde aile katılımı engelleri değişkeni için, aile katılımı etkililiğinin önemli bir aracı değişken olduğu, bu değişkenin sabitlenmesi halinde öğretmenliğe ilişkin tutum değişkeninin düşük etkide olduğu sonuçlarına ulaşılmıştır. Sınıf öğretmenliği öğrencileri öğretmenliğe başladıklarında çocuklarından dolayı ebeveynlerle doğrudan iletişim halinde olacaklardır. Bu nedenle öğretmenin adaylarının tutumu, aile katılımının başlaması, devamlılığının sağlanması ve etkin olarak yürütülmesinde en önemli rol öğretmene düşecektir (Tezel-Şahin ve Ünver, 2005).

Öğretmen adaylarının öğretmenlik öz yeterliğinin aile katılımının etkililiğini ve engellerini benzer şekilde istatistiksel olarak anlamlı bir sonuca ulaşılmıştır. Öğretmenlik öz yeterliğinin yanına aile katılımı etkililiği puanının yordayıcı etkisi katıldığında, iki değişkenin aile katılımı engelleri 
puanını düşük düzeyde açıklamıştır. Cevher-Kalburan (2014) benzer olarak araştırmalarında da öğretmen adaylarının farklı sosyo-ekonomik düzey, farklı dil ve farklı kültürlere sahip ailelere aile katılımı çalışmalarını uygulama şansları olduğunu ve öz yeterliğin aile katılımının önemli bir yorday1cısı olduğu sonucuna ulaşmışlardır. Krizman (2013), çalışmasında öz-yeterlik düzeyi yüksek öğretmenlerin aile katılım etkinliklerine daha fazla vakit ayırdığı sonucuna ulaşmıştır. Kendine güven duymayan bir öğretmenin öğrencileri zorlaması, yeni yöntemler denemesi veya zorluk çekmesi daha az olasıdır. Öğretmenler yeteneklerine güvendiklerinde, zorluklarla ısrarcı olduklarında ve uygulamalarında yenilikçi olduklarında öğrenciler gerçekten faydalı olabilirler. Çocukluk eğitiminde uzmanlaşan bir psikolog olan Anita Woolfolk (2004) "yüksek hedefler belirleyen, 1srar eden, olumsuz bir durumla karşılaşıldığında başka bir strateji deneyen öğretmenler, başka bir deyişle, öz yeterlik duygusu yüksek ve buna göre hareket eden öğretmenlerin öğrenen öğrencileri olması daha muhtemeldir" demektedir (Woolfolk ve Shaughnessy, 2004). Öğretmen adaylarının öz-yeterliklerinin gelişmesi için, üniversite öğrenimleri sürecinde desteklenmeleri gerekmektedir. Lisans eğitimi öğretmen adaylarının öz yeterliklerini geliştirmek amacıyla öğretmenlik mesleğinden zevk alacakları ders ve çalışmalara yer verilmelidir. Öğretmenlik hayatlarında öğrencilerin bütün sorumluluğunun kendi üzerinde olacağ düşüncesi onları öğretmenlik mesleğinden soğutabilir. Bu nedenle aile katılımına engellerin ortadan kaldırılması ve ailelerin eğitim öğretim sürecinin içinde olacaklarını bilmeleri öğretmen öz-yeterliğinin yükselmesini sağlayacaktır.

\section{Öneriler}

Türkiye'de üniversitelerin Okul Öncesi Öğretimi Ders Programı́nda farklı ders dönemlerinde Okul Öncesi Eğitime Giriş, Anne Baba Eğitimi, Okul Öncesinde Dil Kazanımının Desteklenmesi, Okul Öncesinde Özel Öğretim Yöntemleri gibi zorunlu dersler içerisinde aile katılımı eğitimi verilirken sınıf öğretmenliği bölümünde aile katılımı zorunlu ders olarak veya zorunlu derslerin içeriğinde bulunmamaktadır. Sınıf öğretmenliği bölümüne de aile katılımı ile ilgili derslerin eklenmesi öğretmen adaylarının mesleki öz yeterliklerini artıracağından aile katılımı konusundaki engelleri kaldıracaktır. 
Öğretmen adaylarının öğretmenliğe karşı tutum ve genel öz-yeterlik inançlarının geliştirilmesi için öğrenim sürecinde üniversitelerin sosyal, sportif ve kültürel açıdan çeşitli etkinliklerin yapılması önerilmektedir.

Aile katılımı engellerinin aşılmasında aile katılımındaki problemlerin çözümü hakkında öğretmen adayları bilgilendirilmelidir. Öğretmenlik deneyimi amacıyla yapılan stajlarda aile katılımı etkinliklerini gözlemleme ve uygulama fırsatları verilmesi öğretmen adaylarına aile katılım çalışmaları konusunda bir anlayış geliştirmelerine firsat sunabilir. Öğretmenlik uygulaması staj döneminde dersine girdikleri öğrencilerin aileleriyle doğrudan etkileşim kurmalarını ve aile katılım tekniklerini kullanmalarını imkân veren uygulamalar yapmaları istenmelidir.

Sınıf öğretmenlerinin aile katılımı etkinlikleri okullarında bulunan ve üniversite öğreniminde aile katılımı dersi almış olan, okul öncesi öğretmenleriyle beraber hareket ederek onların deneyim ve bilgilerinden yararlanmaları faydalı olacaktır. Son dönemlerde Milli Eğitim Bakanlığı tarafından sınıf öğretmenlerine verilen aile katılımı kurslarının yaygınlaştırılarak öğretmen adaylarının da kurs ve seminerler ile akademik etkinliklere katılmaları teşvik edilmelidir. 
EXTENDED ABSTRACT

\title{
The Effectiveness of Pre-service Teachers' Family Participation and Their Barriers to Family Participation and the Relationship Between Attitude and Professional Self-Efficacy
}

\author{
Songül Tümkaya - Metin Altunkaynak \\ Çukurova University
}

Primary education, which constitutes the first step of basic education, is of great importance both individually and socially. Primary school is a new social environment for children. The new rules that the students must follow in the school, the meeting with the students and teachers in the classroom and the school, the lessons and subjects to be learned and the values they will gain cause problems in adapting to the school environment. Students' utilizing positive attitudes, skills and behaviors as much as possible depends on the functioning of primary school (Özbaş, 2013). Among the functions of the primary school: students can socialize and adapt to the environment and class, provide students with the necessary basic values and increase the academic achievement of students (Ministry of Education (MEB), 2018).

In order for these functions of primary schools to be realized at the desired level, effective cooperation with the families of the pupils is required. From the warm family environment, child who starts school starts the first socialization institution where the rules of living together are valid.

The lack of studies on the effectiveness of prospective teachers about family participation is an important issue. The departments of the faculties of education of universities have a standard curriculum, the content of which is determined by the Council of Higher Education. In this curriculum there is only one compulsory course on family participation. Researches showing the existence of problems related to family participation (İnal, 2006; Erdoğan and Demirkasımoğlu, 2010; Yolcu, 2011) show that more research is needed to investigate and increase the effectiveness of teachers in this field. 
Teacher trainees who received family participation training reported that they were "very prepared" to implement family participation activities compared to those who did not (Katz and Bauch, 1999). When teacher education programs are integrated with teaching and activities within the family participation, teacher candidates have better prepared themselves and formed positive opinions (Uludağ, 2008). Ahioğlu-Lindberg (2014) found that although the prospective teachers who took compulsory family participation courses had positive opinions about family participation, teacher trainees did not implement family participation sufficiently. This study shows that the sources of development of perceptions about the obstacle to family participation emerged in pre-teaching years.

Problems with family participation are defined as; teachers' refusal to invite parents to school activities (Gonzalez-Dehass, 2005), teachers' thoughts that family participation activities would not be beneficial, teachers' facing obstacles (Demircan, 2012) related to communication due to their busy working programs (Baum, 2000). If these are well defined, it becomes easier to understand and overcome them (Keyser, 2006).

In this study, the pre-service teachers' attitudes towards family participation were examined with regard to the barriers to family participation, effectiveness of family participation, attitudes towards teaching, and self-efficacy beliefs and attitudes towards family participation.

This study was designed in a relational survey model aimed at explaining the relationships with independent, mediator and dependent variables within the scope of family participation of prospective teachers. In this model, it is tried to determine the direction and degree of changes between variables without attempting to influence or change (Büyüköztürk, 2018). In this context, research data were analyzed by using quantitative techniques.

Purposeful sampling method and criterion sampling techniques were used in the determination of the study group. Purposeful sampling allows indepth study of situations thought to be rich in information. The purpose of the criterion sampling technique is to ensure that all cases that meet a predetermined set of criteria are studied (Yıldırım \& Şimşek, 2016).

The data of the prospective teachers have been collected through; "Demographic information form", "Family Participation Barriers Scale Form", "Family Participation Effectiveness Scale Evaluation Form", Attitude towards Teaching Scale "and" Teacher Self-Efficacy Scale. 
The data set was created by transferring the scales to the computer environment. Then, end value analyzes were made with the lost data and made suitable for the analysis. The inverse items in the scales were corrected before the analysis and total scores were calculated on the basis of dimensions. Then, the suitability of the data set for multivariate analysis was evaluated.

In the study which aims to explain the relationships with independent, mediator and dependent variables within the scope of family participation of teacher trainees, it is seen that attitudes towards teaching and teaching selfefficacy scores significantly predict the effectiveness of family participation scores. The order of importance on the effectiveness of family participation variable is teacher self-efficacy and the level of attitudes towards teaching. This result shows that teacher candidates who have high self-efficacy and positive attitudes towards teaching give importance to family participation for a more effective teaching process. The more prospective teachers perceive themselves as proficient in terms of profession, the more positive they approach working with families. Pre-service teachers who rely on their own skills and abilities may think that they can overcome the barriers to family participation.

It was concluded that the pre-service teachers' attitude towards teaching and teaching self-efficacy scores significantly predicted the barriers of family participation. The order of importance on the barriers of family participation variable is the level of teaching attitude and teacher self-efficacy. The development of students depends on education. However, no education system can be better than the teacher's quality and skills cannot be developed without the help of the instructor. Teaching Practice 'opportunities are offered to prospective teachers at the university. This practice helps teachers 'behaviors, attitudes and interests shape classroom teachers' personality. Attitude is the tendency to react at a given time. Therefore, prospective teachers' attitudes towards teaching are crucial in many respects, including family participation.

Similarly, the degree of pre-service teachers' attitudes toward teaching predicted the effectiveness and barriers of family participation was statistically significant. It has been concluded that teaching attitude score explains the effectiveness of family participation less and family obstacles more. When the predictive effect of the teaching attitude and the effectiveness of the family participation score were added, it was concluded that the family participation barriers score explained a large part of the total variance. 
According to the research findings, when the role of family participation in the relationship between teacher attitude and family participation barriers is examined, it is seen that family participation effectiveness is an important mediator variable and if this variable was fixed, it was found that the attitude variable about teaching was low.

A statistically significant result was reached in terms of the effectiveness and barriers of family participation of teacher candidates' self-efficacy. When the predictive effect of family participation effectiveness score was added to the teaching self-efficacy, it explained the low level of family participation barriers score of the two variables.

Preschool Education Course Program of the universities in Turkey, at the different course of the semester, Introduction to Preschool Education, Parenting Education, School Support of Pre-school Language Acquisition, Teaching Special Pre-school methods are included as compulsory courses, in the class teacher section, family participation is not a compulsory course or in a compulsory course. Adding the courses related to family participation to the classroom teaching department will increase the professional self-efficacy of the prospective teachers and will remove the obstacles on family participation.

\section{Kaynakça / References}

Abbak, B. S. (2008). Okul öncesi eğitim programlarındaki aile katılımı etkinliklerinin anasınıf öğretmenleri ve veli görüşleri açıcından incelenmesi. Yayımlanmamış yüksek lisans tezi. Çukurova Üniversitesi, Adana.

Ahioğlu-Linberg, E.H. (2014). Final year faculty of education students' views concerning parent involvement. Educational Sciences: Theory ve Practice, 14(4), 1352-1361.

Ajanga, A. J. (2011). Teachers perception, beliefs, and self-efficacy about parental engagement and school family partnerships in Kenya. Yayımlanmamıs Doktora tezi. Woman's Üniversitesi, Texas

Alaçam, N. (2015). Parent involvement self-efficacy beliefs of pre-service early childhood teachers with respect to general self-efficacy beliefs and perceived barriers about parent involvement. (Yayımlanmamış yüksek lisans tezi). Orta Doğu Teknik Üniversitesi, Ankara. 
Ateş, Ö. (2015). Okul öncesi öğretmen adaylarının aile katılım çalışmalarına yönelik öz-yeterlik inançlarının incelenmesi. Yayımlanmamış yüksek lisans tezi. Pamukkale Üniversitesi, Denizli.

Balcı, A. (2007). Karşlaş̧tırmalı eğitim sistemleri. Ankara: Pegem Akademi Yayınları. Bandura, A. (2001). Social cognitive theory: An agentic perspective. Annual Review of Psychology. 52, 1-26.

Baron, R. M. ve Kenny, D. A. (1986). The moderator-mediator variable distinction in social psychological research: Conceptual, strategic, and statistical considerations. Journal of Personality and Social Psychology, 51 (6), 1173-1182.

Baum, A.C. (2000). Exploring beliefs of early childhood pre-service teachers. Yayımlanmamış Doktora tezi. Iowa State Universitesi, ABD.

Berends, M. (2006). Survey Methods in Educational Research. In J. L. Green, (G. Camilli, ve P. B. Elmore Eds.), Handbook of complementary methods in education research içinde (s. 623-640). New Jersey: Lawrence Erlbaum Associates Publishers

Büyüköztürk, Ş., Çakmak, E. K., Akgün, Ö. E., Karadeniz, Ş., ve Demirel, F. (2016). Bilimsel araştırma yöntemleri. Ankara: Pegem Akademi Yayınları.

Büyüköztürk, Ş. (2018). Veri analizi el kitabı. Ankara: Pegem Akademi Yayınları.

By The Room 241 Team, (2018). https://education.cu-portland.edu/blog/curriculum-teaching-strategies/improve-teacher-efficacy/.

Çapa, Y., Çakıroğlu, J., ve Sarıkaya, H. (2005). Öğretmenlik özyeterlik ölçeği Türkçe uyarlamasının geçerlik ve güvenirlik çalışması. Eğitim ve Bilim. 30(137), 74-81

Cevher-Kalburan, F.N.(2014). Early childhood pre-service teachers"e concerns and solutions to overcome them (the case of Pamukkale University). South African Journal of Education, 34(1), 1-18.

Çokluk, Ö., Şekercioğlu, G., ve Büyüköztürk, Ş. (2012). Sosyal bilimler için çok değiskenli istatistik: SPSS ve LISREL uygulamaları. Ankara: Pegem Akademi.

Demircan, H.Ö. (2012). Developmentally appropriate practice and parental involvement in preschools: Parent and teacher perspectives. Yayımlanmamış Doktora tezi. Orta Doğu Teknik Üniversitesi, Ankara.

Erdoğan, Ç. ve Demirkasımoğlu, N. (2010). Ailelerin eğitim sürecine katıl1mina ilişkin öğretmen ve yönetici görüşleri. Educational Administration: Theory and Practice,16(3), 399-431. 
Epstein, J. ve Dauber, S. (1991). School programs and teacher practices of parent involvement in inner-city elementary and middle schools. The Elementary School Journal, 91 (3), 289-305.

Erkuş, A., Sanlı, N., Bağll, M. T., ve Güven, K. (2000). Öğretmenliğe ilişkin tutum ölçeği geliştirilmesi. Eğitim ve Bilim, 25, 116.

Gist, M. E., ve Mitchell, T. R. (1992). Self-efficacy: A theoretical analysis of its determinants and malleability. Academy of Management review, 17(2), 183-211.

Gonzalez-DeHass, A. R. (2005). Facilitating parent involvement:Reflecting on effective teacher education. Teachingve Learning, 19(2), 57-76.

Hornby, G.ve Lafaele, R. (2011). Barriers to parental involvement in education: An explanatory model. Educational Review, 63(1), 37-52.

Horzum, T., Çelik, F., Gök, E., Kumlu, G. D. Y., Şahin, D., Yanış, H., ... , Hac1oğlu, Y. (2016). Sosyal Bilimler Alanlarında hazırlanan tezler için raporlaştırma önerileri: Bir tez nasıl yazılmalıdır?. Gazi Üniversitesi Gazi Eğitim Fakültesi Dergisi, 36(3), 489-521

Hoy, A.W. ve Spero, R.B. (2005). Changes in teacher efficacy during the early years of teaching: A comparison of four measures. Teaching and Teacher Education, 21 (4), 343-356.

İnal, G. (2006). Öğretmenlerin anaokullarn ile anasınıflarındaki programlara ailelerin katılımı konusundaki görüşlerinin değerlendirilmesi.Yayımlanmamış yüksek lisans tezi. Hacettepe Üniversitesi, Ankara.

Judge, T. A., Erez, A., ve Bono, J. E. (1998). The power of being positive: The relation between positive self-concept and job performance. Human performance, 11(2-3), 167-187.

Kablan, Z. (2012). Öğretmen adaylarının ders planı hazırlama ve uygulama becerilerine bilişsel öğrenme ve somut yaşantı düzeylerinin etkisi. Ĕ̆itim ve Bilim, 37, 163.

Katz, L. ve Bauch, J.P. (1999). The peabody family involvement initiative: Preparing pre-service teachers for family/school collaboration. School Community Journal, 9 (1), 185-204.

Kaya, R. (2007). The attitudes of preschool teachers toward parent involvement. Yayımlanmamış yüksek lisans tezi. Orta Doğu Teknik Üniversitesi, Ankara.

Keyser, J. (2006). From parents to partners. building a family-centered early childhood program. Redleaf Press, USA.

Kline, R.B. (2005), Structural equation modeling, 2nd ed., New York: The Guilford Press. 
Krizman, C. (2013). The relationship between teachers" self-efficacy beliefs and parental involvement practices: A multi-method study. Yayımlanmamış Doktora tezi. Texas Tech Universitesi, Texas.

Kurt, T. (2016). Öğretmen liderliğini açıklamaya yönelik bir model: Dağıtımcı liderlik, örgütsel öğrenme ve öğretmenlerin öz yeterlik algisının öğretmen liderliğine etkisi. Ĕgitim ve Bilim, 41, 183.

McBride, B. A. (1991). Preservice teachers' attitude toward parental involvement. Teacher Education Quarterly, 18(4), 57-67.

Okul Öncesi ve İlköğretim Kurumları Yönetmeliği.[MEB]. (2014). Resmi Gazete, 29072 Sayılı.

MEB. (2017) Öğretmenlik mesleği genel yeterlikleri, Öğretmen yetiştirme Geliştirme Genel Müdürlüğü, Ankara.

Morris, V., ve Taylor, S. (1998). Alleviating barriers to family involvement in education: The role of teacher education. Teaching and Teacher Education, 14(2), 219-231.

Özbaş, M. (2009). Illköğretim okulu yöneticilerinin okul-aile ilişkileri konusunda yapmaları gereken ve yapmakta oldukları işler. Yayımlanmamış doktora tezi. Hacettepe Üniversitesi, Ankara.

Özbaş, M. (2013). İlköğretim okulu yöneticilerinin ilköğretim birinci sinıf öğrenci ailelerinin okul yaşamına katılım eğitimi konusundaki görevlerine ilişkin veli algıları. Eğitim ve Bilim, 38, 170.

Tichenor, M.S. (2010). Pre-service teachers' attitudes toward parent involvement: Implications for teacher education. The Teacher Educator, 33(4), 248-259.

Savacool, J.L. (2011). Barriers to Parental Involvement in the Pre-Kindergarten Classroom. Online Submission. 32, 340.

Steven, B.W. (2003). Better Teachers, Better Preschools: Student Achievement Linked to Teacher Qualifications. NIEER Preschool Policy Matters, 2. 1-12

Stuckey, A. (2010). Influences of an overlapping goal-setting strategy on the personal standards and efficacy toward parent involvement in education for preservice teachers. Yayımlanmamış doktora tezi. Northern Illinois Üniversitesi, Illinois.

Tezel-Şahin, F. ve Ünver, N. ve (2005). Okul öncesi eğitim programlarına aile katılımı, Kastamonu Ĕ̆itim Dergisi, 13(1), 23-31.

Temel Eğitim Genel Müdürlüğü, (2018). Çocuğum okula başlıyor, ebeveynler için bilgi klavuzu. Ankara.

Tschannen-Moran, M., Hoy, A. W., ve Hoy, W. K. (1998). Teacher efficacy: Its meaning and measure. Review of educational research, 68(2), 202-248. 
Uludağ, A. (2008). Elementary pre-service teachers' opinions about parental involvement in elementary children's education. Teaching and Teacher Education, 24, 807-817.

Woolfolk, A., ve Shaughnessy, MF (2004). An interview with Anita Woolfolk: The educational psychology of teacher efficacy. Educational psychology review, 16(2), 153-176.

$\mathrm{Wu}, \mathrm{PJ}$ (1995). The relationships of teachers' sense of efficacy and school climate to teachers' parent involvement practices in early childhood programs in Taiwan.Yayınlanmamış Doktora tezi, Vanderbilt Üniversitesi, Nashville.

Yıldırım, A. ve Şimşek, H. (2016). Sosyal bilimlerde nitel araştırma yöntemleri. Ankara: Seçkin Yayınları.

Yolcu, H. (2011). Türkiye' de eğitimde yerelleşme ve ailelerin okul yönetimine katılımının güçlendirilmesi: Değişen ne? Kuram ve Uygulamada Eğitim Bilimleri, 11(3), 1229-1251.

Zygmunt-Fillwalk, E.M. (2006). The difference a course can make: Pre-service teachers' perceptions of efficacy in working with families. Journal of Early Childhood Teacher Education, 27(4), 327-342.

\section{Kaynakça Bilgisi / Citation Information}

Tümkaya, S. ve Altunkaynak, M. (2020). Öğretmen adaylarının aile katılımının etkililiği ve aile katılımına yönelik engelleri ile öğretmenliğe ilişkin tutum ve mesleki öz yeterliklerinin ilişkisi. OPUSUluslararası Toplum Araştırmaları Dergisi, 15(21), 604-632. DOI: 10.26466/opus.657336 